\title{
OPTIMIZATION OF PREVENTIVE THRESHOLD FOR CONDITION- BASED MAINTENANCE OF RADIO ELECTRONIC EQUIPMENT
}

Solomentsev O. V. - Dr. Sc., Professor of the Department of Telecommunication and Radio Electronic Systems, National Aviation University, Kyiv, Ukraine.

Zaliskyi M. Yu.- PhD, Associate Professor of the Department of Telecommunication and Radio Electronic Systems, National Aviation University, Kyiv, Ukraine.

Shcherbyna O. A. - PhD, Associate Professor of the Department of Electronics, Robotics and Technology of Monitoring and Internet of Things, National Aviation University, Kyiv, Ukraine.

Asanov M. M. - PhD, Associate Professor, Simferopol, Ukraine.

\section{ABSTRACT}

Context. Operation costs throughout the life cycle of radio electronic equipment are very significant, which value far exceeds the initial cost of the equipment. Therefore, the up-to-date scientific and technical problem is to minimize operation costs. One of the ways to solve this problem is the introduction of statistical data processing technologies in the operation systems of radio electronic equipment.

Objective. The goal of the paper is to improve the efficiency of thecondition-based maintenance with the determining parameters monitoring, which is widely used in civil aviation.

Method. The solution of this problem is based on finding the functional dependence of the efficiency indicator in the form of specific operation costs on the basic parameters of radio electronic equipment and its operation system. To determine this dependence, the probability-event model is used,as well as methods of probability theory and mathematical statistics, in particular methods of statistical classification of sample sets and functional transformations of random variables. To determine the optimal level of the preventive threshold by the criterion of minimizing operation costs, the method of statistical simulation of Monte-Carlo is used.

Results. Maintenance strategy with the determining parameters monitoring based on additional statistical data processing and technology of the optimal preventive threshold calculation are improved.

Conclusions. The obtained results can be used during the development and modernization of operation systems of radio electronic equipment in terms of application of statistical data processing procedures. A comparative analysis of the two maintenance strategies showed that the use of additional statistical data processing might reduce specific operation costs. The proposed technology for determining the optimal preventive threshold can be extended to use during the operation of complex technical systems, in particular for those whose technical condition is associated with the values of the determining parameters.

KEYWORDS: efficiency indicator, condition-based maintenance, statistical data processing, operation system, radioelectronic equipment.

\section{ABBREVIATIONS}

$\mathrm{CBM}$ is a condition-based maintenance;

$\mathrm{OS}$ is an operation system;

$\mathrm{RCM}$ is a reliability-centered maintenance;

$\mathrm{REE}$ is a radio electronic equipment.

\section{NOMENCLATURE}

$a_{0}$ is an initial determining parameter value in the $\left[P_{-} ; P_{+}\right]$interval;

$a_{1}$ is a tangent of the technical condition deterioration linear trend slope;

$C_{\mathrm{M}}$ and $C_{\mathrm{R}}$ are average costs of maintenance and repair;

$C_{\Sigma}$ is a total operating cost;

$C_{\mathrm{P}}$ and $C_{\mathrm{PM}}$ are the costs of data processing and preventive maintenance, as a result of which failure does not occur;

$h(t)$ is a Heaviside function;

$m_{1}\left(P_{\mathrm{F}}\right)$ and $m_{1}\left(P_{\mathrm{S}}\right)$ are the mathematical expectations of the probability of radio electronic equipment failure and the failure-free operation;
$N$ is a number of elementary sections of $\Delta t$ duration during the observation interval;

$P_{+}$and $P_{-}$are preventive thresholds;

$P_{\mathrm{S}}$ and $P_{\mathrm{F}}$ are statistical estimates of probabilities of failure-free operation and failure of radio electronic equipment;

$\mathrm{O}_{+}$and $\mathrm{O}_{-}$are operational thresholds;

$S_{1}$ is a first strategy;

$S_{2}$ is a second strategy;

$t_{\mathrm{d}}$ is a moment the changepoint beginning;

$T_{\Sigma}$ is an observation interval;

$X(t)$ is a monitoring parameter;

$x(t)$ is a fluctuation component due to the instability of the determining parameter;

$y(t)$ is a determining parameter;

$y_{1}(t)$ is a component that characterizes the trend in a time interval where there is no changepoint;

$y_{2}(t)$ is a component that characterizes the changepoint; 
$\alpha$ is a probability of the first kind error;

$\beta$ is a probability of the second kind error;

$\gamma$ is a dimensionless coefficient;

$\Delta t$ is a time interval;

$\sigma$ is a standard deviation.

\section{INTRODUCTION}

Radioelectronic equipment in civil aviation plays a big role in ensuring the safety and regularity of aircraft flights. There are airborne and ground equipment.

The radioelectronic equipment operation efficiency is related to its reliability [1]. Maintaining the required reliability and efficiency level of equipment usage is the main task of the OS.

The main operation system elements are radioelectronic equipment, processes, personnel, documentation, expandable resources, equipment for measurement and monitoring, etc. The main operation processes are equipment intended use, maintenance, repair, operational data collection and processing, resource extension, flight inspections, storage and disposal [2].

The operation system can be considered as an object of design and improvement [3].

The operation system forms and implements control and corrective actions. Decision making is based on operational strategies, such as condition-based and reliability-based [4]. The condition-based maintenance (CBM) strategy includes control of the determining parameters or reliability level. Another strategy is RCM. $\mathrm{CBM}$ and RCM strategies include data processing procedures, including statistical ones [5]. So in the operation system it is advisable to use algorithms and procedures of statistical data processing in order to make correct and timely decisions during the radioelectronic equipment intended use [6].

The object of study is the process of statistical data processing in the operation system of radio electronic equipment.

The subject of study is the method of determining the optimal values of preventive threshold for conditionbased maintenance of radio electronic equipment.

The purpose of the work is to improve the efficiency of the condition-based maintenance with the determining parameters monitoring, which is widely used in civil aviation.

\section{PROBLEM STATEMENT}

The generalized block diagram of the operation system is shown in Fig. 1.

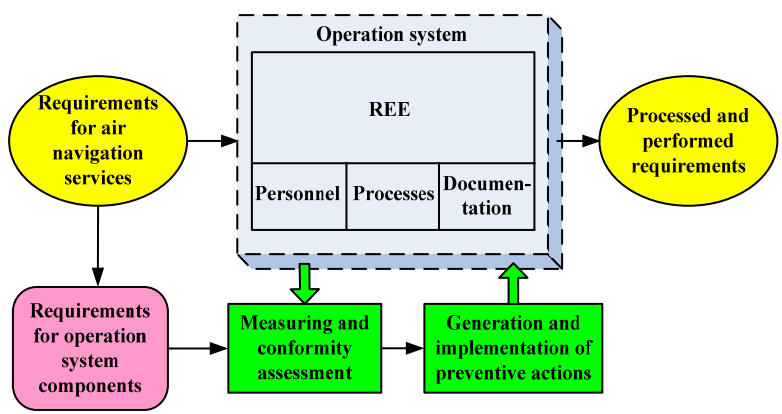

Figure 1 - Generalized block diagram of the OS

The circuit in Fig. 1 is built on the basis of the process approach (ISO 9001) and adaptability and management principles. The main OS element is REE. REEs use traffic control personnel during air traffic control [7]. REE signals in automatic mode are fed to the aircraft.

The task of the operation system elements and its control units is to provide the necessary levels of risk and safety [8]. At the same time, the OS operation costs should be minimal [9].

According to the National transport strategy of Ukraine [10], one of the main tasks is improvement of data collecting and processing. Data processing absence leads to additional costs and reduces efficiency [11].

In author's opinion, an important scientific area is the creation of a methodology for processing operational data and making decisions based on it.

This article discusses two tasks: the task of substantiating the need for statistical processing of operational data for one particular efficiency indicator type; the task of determining the preventive threshold during processing data for the condition-based maintenance strategy.

\section{REVIEW OF THE LITERATURE}

There are various concepts, approaches, regulatory documents in the aviation industry on the basis of which developers create equipment and its operation systems [12]. The modern approach is based on the entire equipment life cycle consideration: planning, design, manufacturing and operation [13].

Promising areas of research in the operation field are: remaining lifetime estimation, improvement of the procedures for diagnosing the technical condition, increasing the reliability of maintenance monitoring, cost optimization, statistical processing of operational data, processes analysis in deteriorating systems [14].

According to the second thermodynamics law, the entropy of any system tends to infinity. That's why, the integrity of the system is violated and the system breaks up into a large number of elements. It is the reason for the occurrence of degradation processes that are characteristic of physical, biological, and social systems [15]. Thus, in technical systems there are technical condition deterioration processes. The model of these processes is an unsteady, random process with two or 
more quasistationary sections [16]. In the literature, such processes are called processes with changepoint.

The changepointis time moment of transition from one stationary condition to another stationary or nonstationary condition. Mathematically the changepoint problem is associated with case when a series of observation contains values with one probability distribution before changepoint occurrence and values with another distribution after it.

Processing operational data of processes with changepoints will allow solving the problems of estimating the residual lifetime [17].

The literature analysis shows that sufficient attention is paid to the theoretical study of processes with changepoints. However, during the design and improvement there are insufficient engineering results in this area.

\section{MATERIALS AND METHODS}

The operation system is a system for managing the condition of REE and other OS elements [16]. The following content is needed for management: "when to do", "what to do", "whom to do", "with what to do". The main thing is the time to perform operational tasks, which is associated with the residual lifetime.

The following indicators are used as an OS efficiency indicator: availability factor, operational availability factor, operating efficiency factor, average risks [18].

In this article, we consider the efficiency indicator in the form of specific operation costs during the one REE operation. The REE technical condition will be characterized by one determining parameter.

In the operational management system for REE, we will consider two options for the maintenance and repair strategy.

The first strategy $S_{1}$ is based on the performing the periodic technical condition monitoring. The determining parameter value is compared with operational tolerances during the monitoring process. If tolerances are exceeded, failures occur and repairs are carried out. In $S_{1}$, the trend analysis of the change in the determining parameter is not performed. Therefore, failures appear suddenly.

During the second $S_{2}$ strategy the statistical processing of operational data is made. This data is the trends of changes in the determining parameters. This strategy allows to evaluate the failure possibility and perform preventive and corrective actions. Repairs are performed in the event of a failure.

The analytical formula for the efficiency indicator can be obtained while using an event-probability model. The main components of this model are events, their probabilities and average costs.

Let us consider the $S_{1}$ strategy. We assume that the efficiency estimation is made on the observation interval $T_{\Sigma}$. The observation interval is divided into $N$ elementary sections of $\Delta t$ duration. During the $\Delta t$ interval, the REE may remain in an serviceable condition or a failure of the REE may occur with subsequent restoration. We assume that the events at different elementary intervals $\Delta t$ are independent.

A random number of failures $n$ may occur in the observation interval $T_{\Sigma}$. The number of events, when there are no failures, is equal to $N-n$.

So, two events are possible in scheduled maintenance $S_{1}$ strategy. Statistical estimates of these events probabilities are the following:

$$
P_{\mathrm{S}}=n / N, \quad P_{\mathrm{F}}=(N-n) / N .
$$

If the model of operating time between failures is known, then it is possible to determine the numerical characteristics of the estimates, at least the mathematical expectation and variance. In this article, as in many other works, we limited ourselves to considering only mathematical expectation.

We assume that in the absence of failure the average costs are equal to $C_{\mathrm{M}}$. If on the $\Delta t$ interval failure occurs, then the costs are equal to $C_{\mathrm{R}}$. Table 1 presents the components of the event-probability model for $S_{1}$ strategy.

Table 1 - Components of an event-probability model for $S_{1}$ strategy

\begin{tabular}{|c|c|c|}
\hline Events & $\begin{array}{c}\text { Statistical estimates } \\
\text { of the probability of } \\
\text { an event }\end{array}$ & $\begin{array}{c}\text { Average costs due to } \\
\text { an event }\end{array}$ \\
\hline $\begin{array}{c}\text { Serviceable } \\
\text { condition over time } \\
\Delta t\end{array}$ & $P_{\mathrm{S}}$ & $C_{\mathrm{M}}$ \\
\hline $\begin{array}{c}\text { Failure and } \\
\text { maintenance }\end{array}$ & $P_{\mathrm{F}}$ & $C_{\mathrm{R}}$ \\
\hline
\end{tabular}

Let us make an expression for the effectiveness indicator of the $S_{1}$ strategy based on Table 1:

$$
E=m_{1}\left(C_{\Sigma} / S_{1}\right)=m_{1}\left(P_{\mathrm{S}}\right) C_{\mathrm{M}}+m_{1}\left(P_{\mathrm{F}}\right) C_{\mathrm{R}},
$$

where $m_{1}\left(P_{\mathrm{F}}\right)$ and $m_{1}\left(P_{\mathrm{S}}\right)$ are the mathematical expectations of the probability of REE failure and the failure-free operation in the $\Delta t$ interval, respectively; $C_{\Sigma}$ are the total operating costs.

Let us draw up a similar table of the eventprobability model for $S_{2}$ strategy. Since the $S_{2}$ strategy involves making decisions based on data processing, the table will be more complex. It will contain the following components: event, event probability, possible decisions based on processing the operational data and their probabilities, as well as average costs.

Table 2 presents the components of the eventprobability model for $S_{2}$ strategy. For the second strategy, an event of the possible failure occurrence is introduced. In this case, data processing algorithms can detect or skip it. 
Table 2 - Components of the event-probability model for $S_{2}$ strategy

\begin{tabular}{|c|c|c|c|c|}
\hline Events & $\begin{array}{c}\text { Statistical estimates of the } \\
\text { probability of an event }\end{array}$ & $\begin{array}{l}\text { The decision on the technical } \\
\text { condition of the REE }\end{array}$ & $\begin{array}{c}\text { Probability of } \\
\text { a decision }\end{array}$ & Average costs \\
\hline \multirow{2}{*}{ Serviceable condition over time $\Delta t$} & \multirow{2}{*}{$P_{\mathrm{S}}$} & REE operable & $1-\alpha$ & $C_{\mathrm{P}}$ \\
\hline & & REE inoperable & $\alpha$ & $C_{\mathrm{P}}+C_{\mathrm{M}}$ \\
\hline \multirow[b]{2}{*}{ Failure and maintenance } & \multirow[b]{2}{*}{$P_{\mathrm{F}}$} & REE operable & $\beta$ & $C_{\mathrm{P}}+C_{\mathrm{R}}$ \\
\hline & & $\begin{array}{l}\text { REE inoperable (preventive } \\
\text { maintenance) }\end{array}$ & $1-\beta$ & $C_{\mathrm{P}}+C_{\mathrm{PM}}$ \\
\hline
\end{tabular}

In Table 2, the values of $C_{\mathrm{P}}$ and $C_{\mathrm{PM}}$ are the costs of data processing and preventive maintenance, as a result of which failure does not occur; $\alpha$ is the conditional probability of making a decision about an inoperative condition in the absence of failure; $\beta$ is the conditional probability of making a decision about an operable condition in the presence of failure.

Based on Table 2, let us make an expression for the effectiveness indicator of $S_{2}$ strategy:

$$
\begin{gathered}
E=m_{1}\left(C_{\Sigma} / S_{2}\right)=m_{1}\left(P_{\mathrm{S}}\right)\left((1-\alpha) C_{\mathrm{P}}+\alpha\left(C_{\mathrm{P}}+C_{\mathrm{M}}\right)\right)+ \\
m_{1}\left(P_{\mathrm{F}}\right)\left(\beta\left(C_{\mathrm{P}}+C_{\mathrm{R}}\right)+(1-\beta)\left(C_{\mathrm{P}}+C_{\mathrm{PM}}\right)\right) .
\end{gathered}
$$

Let us compare the effectiveness of $S_{1}$ and $S_{2}$ strategies by calculating the dimensionless coefficient $\gamma$ of the following form:

$$
\gamma=\frac{m_{1}\left(C_{\Sigma} / S_{1}\right)}{m_{1}\left(C_{\Sigma} / S_{2}\right)}
$$

After mathematical simplifications, we obtain the following expression:

$$
\gamma=\frac{C_{\mathrm{R}}+m_{1}\left(P_{\mathrm{S}}\right)\left(C_{\mathrm{M}}-C_{\mathrm{R}}\right)}{C_{\mathrm{P}}+C_{\mathrm{F}}+m_{1}\left(P_{\mathrm{S}}\right)\left(\alpha C_{\mathrm{M}}-C_{\mathrm{F}}\right)},
$$

where $C_{\mathrm{F}}=C_{\mathrm{PM}}+\beta C_{\mathrm{R}}-\beta C_{\mathrm{PM}}$.

To analyze the coefficient $\gamma$, we calculate its limit ratios, on the assumption of $\alpha=\beta=0$ :

$$
\gamma(\alpha=\beta=0)=\frac{C_{\mathrm{R}}+m_{1}\left(P_{\mathrm{S}}\right)\left(C_{\mathrm{M}}-C_{\mathrm{R}}\right)}{C_{\mathrm{P}}+C_{\mathrm{PM}}-m_{1}\left(P_{\mathrm{S}}\right) C_{\mathrm{PM}}} .
$$

If we assume that $C_{\mathrm{P}}<<C_{\mathrm{R}}$, then after dividing the numerator and denominator by $C_{\mathrm{R}}$, we get:

$$
\begin{gathered}
\gamma(\alpha=\beta=0) \approx \frac{m_{1}\left(P_{\mathrm{S}}\right) \frac{C_{\mathrm{M}}}{C_{\mathrm{R}}}+\left(1-m_{1}\left(P_{\mathrm{S}}\right)\right)}{\frac{C_{\mathrm{PM}}}{C_{\mathrm{R}}}\left(1-m_{1}\left(P_{\mathrm{S}}\right)\right)}= \\
=\frac{C_{\mathrm{M}}}{C_{\mathrm{PM}}} \frac{m_{1}\left(P_{\mathrm{S}}\right)}{\left(1-m_{1}\left(P_{\mathrm{S}}\right)\right)}+\frac{C_{\mathrm{R}}}{C_{\mathrm{PM}}} .
\end{gathered}
$$

From this ratio it follows that for more reliable equipment $\left(m_{1}\left(P_{\mathrm{S}}\right) \rightarrow 1\right)$, the value $\gamma>>1$. Therefore, the application of $S_{2}$ strategy is more appropriate.

Consider the option of calculating the limit ratio for the case of highly reliable equipment $\left(m_{1}\left(P_{S}\right) \rightarrow 1\right)$ and the first and second kind errors presence. Then we write the coefficient $\gamma$ in the following form:

$$
\gamma\left(m_{1}\left(P_{\mathrm{S}}\right) \rightarrow 1\right) \approx \frac{C_{\mathrm{M}}}{C_{\mathrm{P}}+\alpha C_{\mathrm{M}}}
$$

Since $C_{\mathrm{P}}<<C_{\mathrm{M}}$, we get:

$$
\gamma\left(m_{1}\left(P_{\mathrm{S}}\right) \rightarrow 1\right) \approx \frac{1}{\alpha}
$$

It follows that the application of $S_{2}$ strategy is more preferable.

Nomograms of the coefficient $\gamma$ dependence on conditional probabilities $\alpha, \beta$ and the probabilities of the REE operational condition for the cost option $C_{\mathrm{P}}=5$, $C_{\mathrm{PM}}=50, C_{\mathrm{M}}=75, C_{\mathrm{R}}=500$ are shown in Fig. 2 .

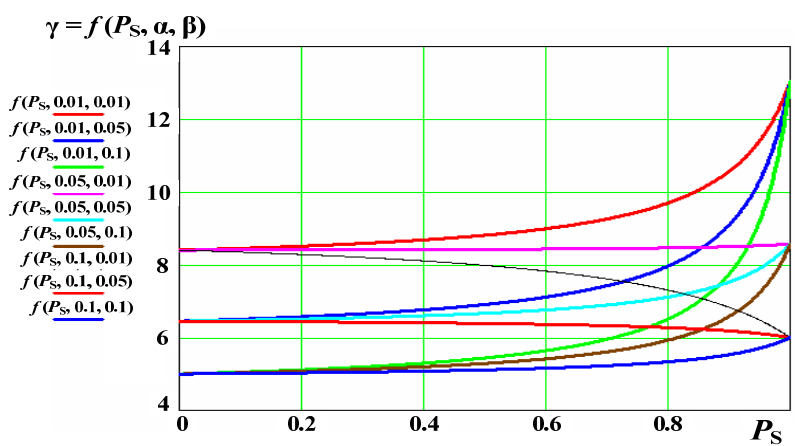

Figure 2 - Nomograms of the coefficient $\gamma$ dependence

As can be seen from the graphs in Fig. 2, the coefficient $\gamma>1$ for all initial data variants. This indicates that the use of the operational data processing by algorithm is reasonable and appropriate.

\section{EXPERIMENTS}

Preventive actions are possible in $S_{2}$ strategy. These actions can be carried out in various ways. In this paper, 
we consider a variant connected with the preventive threshold presence [19]. Having a preventive threshold will eliminate potential failure [20].

Fig. 3 shows the trend of the monitoring parameter $X(t)$. Preventive thresholds are marked as $P_{+}$and $P_{-}$, operational thresholds - as $O_{+}$and $O_{-}$.

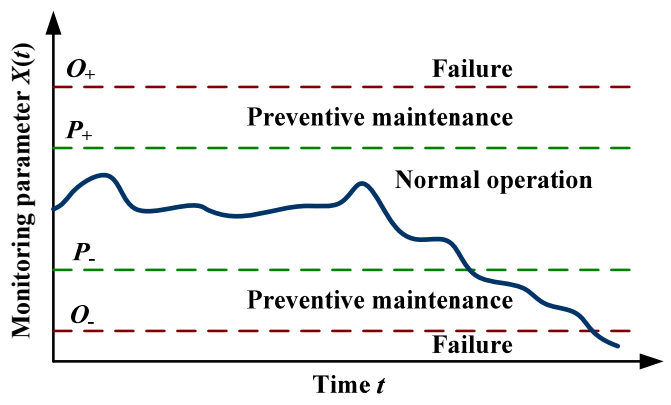

Figure 3 - The monitoring parameter trend

In accordance with $S_{2}$ strategy, the monitoring parameter values can be in one of three areas:

1) a normal operation area

$$
P_{-} \leq X(t) \leq P_{+} ;
$$

2) an area of planning and performing the preventive maintenance

$$
O_{-} \leq X(t)<P_{-} ; P_{+}<X(t) \leq O_{+} ;
$$

3) an area of inoperative state

$$
X(t)<O_{-} ; X(t)>O_{+} .
$$

In the normal operation area, periodic monitoring is carried out using computer technology.

In the malfunctioning area, current repair is performed. After performing it, the REE is operational in the considered determining parameter.

In the case when $P_{+}=O_{+}$and $P_{-}=O_{-}$, the $S_{2}$ strategy coincides by nature with the $S_{1}$ strategy.

Let us perform statistical simulation of $S_{2}$ strategy based on the Monte-Carlo method. The main task of simulation will be to determine the optimal decision making threshold for preventive maintenance performing.

We will present the operational data in the statistical model form of the determining parameter trend of this kind:

$$
y(t)=y_{1}(t)+y_{2}(t)
$$

where $y_{1}(t)$ is a component that characterizes the trend in a time interval where there is no changepoint; $y_{2}(t)$ is a component that characterizes the changepoint.

In this study, we consider the following version of the trend components models of determining parameter:

$$
y_{1}(t)=a_{0}+x(t)
$$

where $a_{0}$ is the initial determining parameter value in the $\left[P_{-} ; P_{+}\right]$interval; $x(t)$ is the fluctuation component due to the instability of the determining parameter, errors in the measuring equipment, etc. An automatic monitoring system of the REE condition is used in $S_{2}$ strategy. The measurement period is very short. The initial measurement results $y_{1}(t)$ averaging is performed to reduce fluctuation amplitudes.

During modeling, we assume that after maintenance and repair:

$$
a_{0}=\frac{P_{-}+P_{+}}{2} .
$$

The fluctuation component has a Gaussian model with zero mathematical expectation and a given standard deviation $\sigma$.

The $y_{2}(t)$ component will be represented by the following model:

$$
y_{2}(t)=a_{1}\left(t-t_{\mathrm{d}}\right) h\left(t-t_{\mathrm{d}}\right)
$$

where $a_{1}$ is the tangent of the technical condition deterioration linear trend slope; $t_{\mathrm{d}}$ is the moment the changepoint begins; $h(t)$ is the Heaviside function.

In the general case $a_{1}$ and $t_{\mathrm{d}}$ values may be random. In this paper, we assume that they are described by a uniform distribution.

Let us describe the initial group of parameters that must be set to describe the OS:

1) the determined temporal characteristics of the model: the observation interval $T_{\Sigma}$, the duration of the scheduled maintenance preparation and performing, the repair duration $t_{\mathrm{R}}$, the control operations frequency (system time) $t_{\mathrm{c}}$;

2) the determined parameters that characterize the average cost of processing $C_{\mathrm{P}}$, preventive maintenance $C_{\mathrm{PM}}$ and repair $C_{\mathrm{R}}$;

3 ) the random variables that are characterized by probabilistic laws: $x(t), a_{1}$ and $t_{\mathrm{d}}$.

During simulation, we assume that the normal distribution law describes the fluctuation component. Therefore, as a result of averaging the $y_{1}(t)$, we also obtain a normal distribution with a standard deviation, depending on the number of samples during averaging.

When modeling the $y_{2}(t)$ component, assumptions were made about the uniform probability density function of $a_{1}$ and $t_{\mathrm{d}}$ values.

As a result of simulation, we will estimate the efficiency indicator in the form of total costs per unit:

$$
E^{*}=\frac{m_{1}\left(C_{\Sigma} / S_{2}\right)}{T_{\Sigma}}
$$


The efficiency indicator in general case is a function of the preventive threshold value $P_{+}$(or $P_{-}$). The simulation process solves the problem of finding the minimum effectiveness estimation $E^{*}$ value and the preventive threshold value that corresponds to it.

\section{RESULTS}

The initial data for simulation are such values: $C_{\mathrm{P}}=0.01, C_{\mathrm{PM}}=100, C_{\mathrm{R}}=1000, t_{\mathrm{c}}=1, t_{\mathrm{PM}}=40$, $t_{\mathrm{R}}=300, \quad \sigma=10, a_{0}=200, O_{+}=300, O_{-}=100$. The observation period is a random variable, but the maximum number of possible failures is $n=40$. The changepoint beginning moment is described by a uniform probability density function in the $[50 ; 100]$ interval. The deterioration trend slope is also uniform in the $[-75 ;-30]$ interval.

An example of the determining parameter trend implementation for the given initial data set is presented in Fig. 4.

Figure 4 shows the determining parameter trend over three possible events in the OS. The first event is a case of prevented failure. At the same time, in OS managed to perform preventative maintenance. The second and third events correspond to the case when the failure occurs. At the same time, in OS there is no time to perform preventive maintenance.

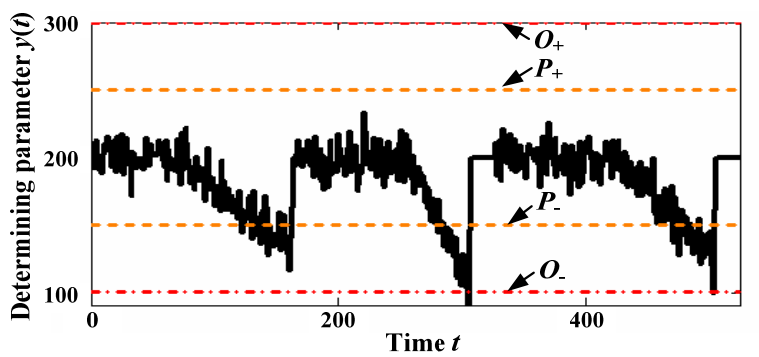

Figure 4 - An example of the determining parameter trend implementation

An example of a single procedure for evaluating the efficiency indicator for different values of the preventive threshold for the given initial data set is shown in Fig. 5.

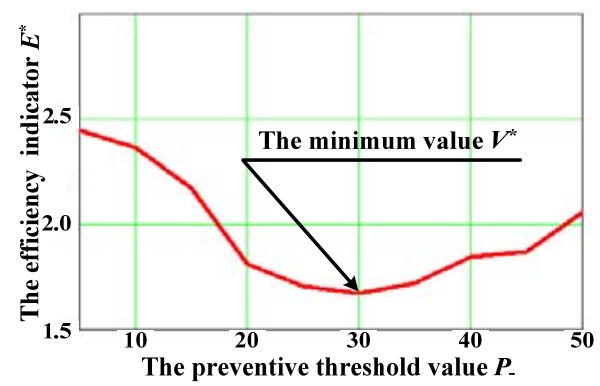

Figure 5 - The efficiency indicator estimates dependence on the preventive threshold value

The number of simulation procedures is 100 . In each simulation procedure, the minimum value estimation is a random variable. Therefore, it is advisable to calculate the mathematical expectation of the optimal value.

For a more accurate estimate of the $V^{*}$ minimum value, the least-squares method approximation using a polynomial of the third degree is used in each simulation procedure. Such actions correspond to the proposed simulation-analytical-calculation method.

As a result, the mathematical expectation of optimal preventive threshold estimation is obtained $m_{1}^{*}\left(V^{*}\right)=30.845$.

\section{DISCUSSION}

From the obtained results, the following conclusions can be made.

Operation is the longest period of the life cycle of REE and other technical systems. The analysis shows that operation costs are a significant value that exceeds the initial cost of the equipment. Therefore, the task of reducing operation costs deserves the attention of scientists.

The most common equipment maintenance strategy is the condition-based maintenance with the determining parameters monitoring. Authors proposed to improve this strategy by using additional statistical processing of determining parameters.

Analysis of scientific results has shown that not enough attention is paid to optimizing the preventive threshold, which is an integral part of the maintenance strategy. Therefore, the article defines a new efficiency indicator based on the use of probabilistic-event model. This model reflects the application of the method of statistical classification of radio electronic equipment technical condition and is used to find the analytical formula for the efficiency indicator. The efficiency indicator also takes into account the model of the determining parameter, which is the basis for solving the problem of finding the preventive threshold optimal value.

The simulation results analysis shows that the dependence $E^{*}=f\left(V^{*}\right)$ always has a minimum.

\section{CONCLUSIONS}

The article considers the task of substantiating the appropriateness of using statistical data processing in the REE operation system. An efficiency indicator in the form of average total costs is proposed. For this indicator, a comparative analysis of two strategies for planning and performing maintenance and repair work was carried out: $S_{1}$ strategy of performing periodic maintenance without trend analysis of the change in the determining parameter; $S_{2}$ strategy of performing preventive maintenance based on the statistical data analysis. For the performance indicator nomograms were built, which showed that $S_{2}$ strategy is more effective than $S_{1}$. 
Performance indicator is a function of the possible failures probability. Such failures can be eliminated using preventative maintenance. Therefore, a maintenance strategy with a preventive threshold was considered. This strategy helps to prevent possible failures and therefore reduces operating costs. The effectiveness analysis of the maintenance strategy with a preventive threshold was carried out based on the Monte-Carlo method. The problem of optimizing the preventive threshold value is solved based on the simulation results. This result was obtained using the analytical-calculation-modeling method.

The obtained results can be used during the design of new statistical data processing subsystem in the operation systems of REE.

The scientific novelty. The article proposes the method for determining the optimal preventive threshold for the condition-based maintenance strategy, this method is based on statistical processing of operational data represented by trends of the determining parameters.

The practical significance. The application of the method allows reducing the specific operation costs during radioelectronic equipment intended use.

Prospects for further research. Further research studies could be associated with determining analytical formulas for the optimal values of the preventive threshold, the use of different models of probability density functions of determining parameters trends, the use of more complex statistical processing, in particular the application of procedures for technical condition forecasting.

\section{REFERENCES}

1. Zhukov I.A. Implementation of integral telecommunication environment for harmonized air traffic control with scalable flight display systems, Aviation, 2010, Vol. 14, No. 3, pp. 117-122.

2. Zaliskyi M., Petrova Yu., Asanov M., Bekirov E. Statistical data processing during wind generators operation, International Journal of Electrical and Electronic Engineering \& Telecommunications, 2019, Vol. 8, No. 1, pp. 33-38. DOI:10.18178/ijeetc.8.1.33-38

3. Solomentsev O., Zaliskyi M., Herasymenko T., Kozhokhina O., Petrova Yu. Data Processing in Case of Radio Equipment Reliability Parameters Monitoring, Advances in Wireless and Optical Communications (RTUWO 2018). Latvia, 15-16 November, 2018: proceedings. Riga, 2018, pp. 219-222.

4. Gertsbakh I. Reliability theory: with applications to preventive maintenance. New York, Springer, 2005, 219 p.

5. Zaliskyi M., Solomentsev O. Method of sequential estimation of statistical distribution parameters, IEEE 3rd International Conference Methods and Systems of Navigation and Motion Control (MSNMC),Ukraine, 14-17 October, 2014: proceedings. Kyiv, 2014, pp. 135-138.

6. Prokopenko I. G., Migel S. V., Prokopenko K. I. Signal modeling for the efficient target detection tasks, International Radar Symposium, Germany, 19-21 June, 2013: proceedings. Dresden, 2013, pp. 976-982.
7. Kharchenko V. P., Kuzmenko N. S., Ostroumov I. V. Identification of unmanned aerial vehicle flight situation, IEEE 4th International Conference on Actual Problems of Unmanned Aerial Vehicles Developments (APUAVD), Ukraine, October, 2017: proceedings. Kyiv, 2017, pp. 116120.

8. Kuzmenko N. S., Ostroumov I. V., Marais K.An accuracy and availability estimation of aircraft positioning by navigational aids, IEEE International Conference on Methods and Systems of Navigation and Motion Control (MSNMC), Ukraine, 16-18 October, 2018: proceedings. Kyiv, 2018, pp. 36-40.

9. Jardine A. K. S., Tsang A. H. C. Maintenance, replacement, and reliability: theory and applications, Second edition. BocaRaton, CRC Press, 2017, 364 p.

10. Natsional'na transportna stratehiya Ukrayiny na period do 2030 roku [Electronic resource]. Access mode: https://zakon.rada.gov.ua/laws/show/430-2018-p.

11. Grall A., Dieulle L., Bérenguer C., Roussignol M. Continuous-time predictive-maintenance scheduling for a deteriorating system, IEEE Transactions on reliability, 2002, Vol. 51, No. 2, pp. 141-150. DOI: 10.1109/TR.2002.1011518

12. Nakagawa T. Maintenance theory of reliability. London, Springer-Verlag, 2005, $270 \mathrm{p}$.

13. Galar D., Sandborn P., Kumar U. Maintenance costs and life cycle cost analysis. BocaRaton, CRC Press, 2017, 492 p.

14. Solomentsev O., Zaliskyi M., Zuiev O. Estimation of quality parameters in the radio flight support operational system, Aviation, 2016, Vol. 20, No. 3, pp. 123-128. DOI: $10.3846 / 16487788.2016 .1227541$

15. Goncharenko A. Aircraft operation depending upon the uncertainty of maintenance alternatives, Aviation, 2017, Vol. 21, No. 4, pp. 126-131. DOI: 10.3846/16487788.2017.1415227.

16. Solomentsev O., Zaliskyi M., Herasymenko T., Kozhokhina O., Petrova Yu. Efficiency of Operational Data Processing for Radio Electronic Equipment, Aviation, 2019, Vol. 23, No. 3, pp. 71-77.

17. Hryshchenko Y. V. Reliability problem of ergatic control systems in aviation, IEEE 4th International Conference on Methods and Systems of Navigation and Motion Control (MSNMC), Ukraine, 18-20 October, 2016: proceedings. Kyiv, 2016, pp. 126-129.

18. Volianskyi R., Sadovoi O., Volianska N., Sinkevych O. Construction of Parallel Piecewise-Linear Interval Models for Nonlinear Dynamical Objects, 9th International Conference on Advanced Computer Information Technologies (ACIT), Czech Republic, 5-7 June, 2019:proceedings. Ceske Bidejovice, 2019, pp. 97-100.

19. Huynh K. T., Grall A., Bérenguer C. A parametric predictive maintenance decision-making framework considering improved system health prognosis precision, IEEE Transactions on Reliability, Institute of Electrical and Electronics Engineers, 2018, Vol. 68, No. 1, pp. 375-396. DOI:10.1109/TR.2018.2829771.

20. Sun Q., Ye Z.-S., Peng W. Scheduling preventive maintenance considering the saturation effect, IEEE Transactions on reliability, Institute of Electrical and Electronics Engineers, 2019, Vol. 68, No. 2, pp. 741-752. DOI: $10.1109 /$ TR.2018.2874265.

Received 26.10.2020. Accepted 21.03.2021. 


\section{ОПТИМІЗАЦІЯ ПРЕВЕНТИВНОГО ПОРОГУ ПІД ЧАС ТЕХНІЧНОГО ОБСЛУГОВУВАННЯ ЗА СТАНОМ РАДІОЕЛЕКТРОННОГО ОБЛАДНАННЯ}

Соломенцев О. В. - д-р техн. наук, професор кафедри телекомунікаційних та радіоелектронних систем, Національний авіаційний університет, Київ, Україна.

Заліський М. Ю. - канд. техн. наук, доцент кафедри телекомунікаційних та радіоелектронних систем, Національний авіаційний університет, Київ, Україна.

Щербина О. А. - канд. техн. наук, доцент кафедри електроніки, робототехніки і технологій моніторингу та інтернету речей, Національний авіаційний університет, Київ, Україна.

Асанов М. М. - канд. техн. наук, Сімферополь, Україна.

Актуальність. Експлуатаційні витрати протягом всього життєвого циклу радіоелектронного обладнання складають значну величину, що набагато перевищує власне вартість обладнання. Тому актуальною науково-технічною проблемою $\epsilon$ мінімізація експлуатаційних витрат. Одним із шляхів вирішення цієї проблеми є впровадження технологій оброблення статистичних даних у системах експлуатації радіоелектронного обладнання.

Мета роботи - підвищення ефективності стратегії технічного обслуговування за станом з контролем визначальних параметрів, яка широко застосовується в цивільній авіації.

Метод. Вирішення поставленої проблеми базується на знаходженні функціональної залежності показника ефективності у вигляді питомих експлуатаційних витрат від основних параметрів радіоелектронного обладнання та системи його експлуатації. Для визначення цієї залежності використовується імовірнісно-подієва модель, а також методи теорії ймовірності та математичної статистики, зокрема методи статистичної класифікації вибіркових сукупностей та функціональних перетворень випадкових величин. Для визначення оптимального рівня превентивного порога за критерієм мінімізації експлуатаційних витрат використовується метод статистичного моделювання Монте-Карло.

Результати. Удосконалена стратегія технічного обслуговування за станом 3 контролем визначальних параметрів, що базується на додатковій статистичній обробці експлуатаційних даних та технології знаходження оптимального превентивного порогу.

Висновки. Отримані результати можуть бути використані під час розробки та модернізації систем експлуатації радіоелектронного обладнання в частині застосування процедур оброблення статистичних даних. Порівняльний аналіз двох стратегій технічного обслуговування показав, що використання додаткової статистичної обробки даних дозволяє зменшити питомі експлуатаційні втрати. Запропонована технологія визначення оптимального превентивного порогу може бути поширена для використання під час експлуатації складних технічних систем, зокрема для таких, чий технічний стан пов'язаний зі значеннями визначальних параметрів.

КЛЮЧОВІ СЛОВА: показник ефективності, технічне обслуговування за станом, статистична обробка даних, система експлуатації, радіоелектронне обладнання.

УДК 621.396.6.004.15

\section{ОПТИМИЗАЦИЯ ПРЕВЕНТИВНОГО ПОРОГА ВО ВРЕМЯ ТЕХНИЧЕСКОГО ОБСЛУЖИВАНИЯ ПО СОСТОЯНИЮ РАДИОЭЛЕКТРОННОГО ОБОРУДОВАНИЯ}

Соломенцев А. В. - д-р техн. наук, профессор кафедры телекоммуникационных та радиоэлектронных систем, Национальный авиационный университет, Киев, Украина.

Залиский М. Ю. - канд. техн. наук, доцент кафедры телекоммуникационных та радиоэлектронных систем, Национальный авиационный университет, Киев, Украина.

Щербина О. А. - канд. техн. наук, доцент кафедры электроники, робототехники и технологий мониторинга и интернета вещей, Национальный авиационный университет, Киев, Украина.

Асанов М. М. - канд. техн. наук, Симферополь, Украина.

\section{АННОТАЦИЯ}

Актуальность. Эксплуатационные расходы в течение всего жизненного цикла радиоэлектронного оборудования составляют значительную величину, намного превышающую собственно стоимость оборудования. Поэтому актуальной научно-технической проблемой является минимизация эксплуатационных затрат. Одним из путей решения этой проблемы является внедрение технологий обработки статистических данных в системах эксплуатации радиоэлектронного оборудования.

Цель работы - повышение эффективности стратегии технического обслуживания по состоянию с контролем определяющих параметров, которая широко применяется в гражданской авиации.

Метод. Решение поставленной проблемы базируется на нахождении функциональной зависимости показателя эффективности в виде удельных эксплуатационных расходов от основных параметров радиоэлектронного оборудования и системы его эксплуатации. Для определения этой зависимости используется вероятностно-событийная модель, а также методы теории вероятности и математической статистики, в частности методы статистической классификации выборочных совокупностей и функциональных преобразований случайных величин. Для определения оптимального уровня превентивного порога по критерию минимизации эксплуатационных расходов используется метод статистического моделирования Монте-Карло.

(C) Solomentsev O. V., Zaliskyi M. Yu., Shcherbyna O. A., Asanov M. M., 2021

DOI 10.15588/1607-3274-2021-2-2 
Результаты. Усовершенствована стратегия технического обслуживания по состоянию с контролем определяющих параметров, основанная на дополнительной статистической обработке эксплуатационных данных и технологии нахождения оптимального превентивного порога.

Выводы. Полученные результаты могут быть использованы во время разработки и модернизации систем эксплуатации радиоэлектронного оборудования в части применения процедур обработки статистических данных. Сравнительный анализ двух стратегий технического обслуживания показал, что использование дополнительной статистической обработки данных позволяет уменьшить удельные эксплуатационные затраты. Предложенная технология определения оптимального превентивного порога может быть распространена для использования при эксплуатации сложных технических систем, в частности для таких, чье техническое состояние связано со значениями определяющих параметров.

КЛЮЧЕВЫЕ СЛОВА: показатель эффективности, техническое обслуживание по состоянию, статистическая обработка данных, система эксплуатации, радиоэлектронное оборудование.

\section{ЛІТЕРАТУРА / ЛИТЕРАТУРА}

1. Zhukov I. A. Implementation of integral telecommunication environment for harmonized air traffic control with scalable flight display systems // Aviation. - 2010. - Vol. 14, № 3. P. 117-122.

2. Statistical data processing during wind generators operation / [M. Zaliskyi, Yu. Petrova, M. Asanov, E. Bekirov] // International Journal of Electrical and Electronic Engineering \& Telecommunications. - 2019. Vol. 8, № 1. - P. 33-38. DOI:10.18178/ijeetc.8.1.33-38

3. Data Processing in Case of Radio Equipment Reliability Parameters Monitoring / [O. Solomentsev, M. Zaliskyi, T. Herasymenko et al] // Advances in Wireless and Optica Communications (RTUWO 2018), Latvia, 15-16 November, 2018: proceedings. - Riga, 2018. - P. 219-222.

4. Gertsbakh I. Reliability theory: with applications to preventive maintenance / I. Gertsbakh. - New York : Springer, 2005. -219 p.

5. Zaliskyi M. Method of sequential estimation of statistical distribution parameters / M. Zaliskyi, O. Solomentsev // IEEE 3rd International Conference Methods and Systems of Navigation and Motion Control (MSNMC), Ukraine, 14-17 October, 2014 : proceedings. - Kyiv, 2014. - P. 135-138.

6. Prokopenko I. G. Signal modeling for the efficient target detection tasks / I. G. Prokopenko, S. V. Migel, K. I. Prokopenko // International Radar Symposium, Germany, 19-21 June, 2013: proceedings. - Dresden, 2013. - P. 976-982.

7. Kharchenko V. P. Identification of unmanned aerial vehicle flight situation / V. P. Kharchenko, N. S. Kuzmenko, I. V. Ostroumov // IEEE 4th International Conference on Actual Problems of Unmanned Aerial Vehicles Developments (APUAVD), Ukraine, October, 2017: proceedings. - Kyiv, 2017. - P. 116-120.

8. Kuzmenko N. S. An accuracy and availability estimation of aircraft positioning by navigational aids / N. S. Kuzmenko, I. V. Ostroumov, K. Marais // IEEE International Conference on Methods and Systems of Navigation and Motion Control (MSNMC), Ukraine, 16-18 October, 2018: proceedings. - Kyiv, 2018. - P. 36-40.

9. Jardine A. K. S. Maintenance, replacement, and reliability: theory and applications, Second edition / A. K. S. Jardine, A. H. C. Tsang. - BocaRaton : CRC Press, 2017. - 364 p.

10. Національна транспортна стратегія України на період до 2030 року [Електронний ресурс]. - Режим доступу: https://zakon.rada.gov.ua/laws/show/430-2018-p.
11. Continuous-time predictive-maintenance scheduling for a deteriorating system / [A. Grall, L. Dieulle, C. Bérenguer, M. Roussignol] // IEEE Transactions on reliability. 2002. - Vol. 51, № 2. - P. 141-150. DOI: 10.1109/TR.2002.1011518

12. Nakagawa T. Maintenance theory of reliability / T. Nakagawa. - London : Springer-Verlag, 2005. - 270 p.

13. GalarD.Maintenance costs and life cycle cost analysis D. Galar, P. Sandborn, U. Kumar. - BocaRaton : CRC Press, 2017. - 492 p.

14. Solomentsev O. Estimation of quality parameters in the radio flight support operational system / O. Solomentsev, M. Zaliskyi, O. Zuiev // Aviation. - 2016. - Vol. 20, № 3. P. 123-128. DOI: 10.3846/16487788.2016.1227541.

15. Goncharenko A. Aircraft operation depending upon the uncertainty of maintenance alternatives / A. Goncharenko // Aviation. - 2017. - Vol. 21, № 4. - P. 126-131. DOI: 10.3846/16487788.2017.1415227.

16. Efficiency of Operational Data Processing for Radio Electronic Equipment / [O. Solomentsev, M. Zaliskyi, T. Herasymenko et al.] // Aviation. - 2019. - Vol. 23, № 3. -P. 71-77.

17. Hryshchenko Y. V. Reliability problem of ergatic control systems in aviation / Y. V. Hryshchenko // IEEE 4th International Conference on Methods and Systems of Navigation and Motion Control (MSNMC), Ukraine, 18-20 October, 2016 : proceedings. - Kyiv, 2016. - P. 126-129.

18. Construction of Parallel Piecewise-Linear Interval Models for Nonlinear Dynamical Objects / [R. Volianskyi, O. Sadovoi, N. Volianska, O. Sinkevych] // 9th International Conference on Advanced Computer Information Technologies (ACIT), Czech Republic, 5-7 June, 2019: proceedings. - Ceske Bidejovice, 2019. - P. 97-100.

19. Huynh K. T. A parametric predictive maintenance decisionmaking framework considering improved system health prognosis precision / K. T. Huynh, A. Grall, C. Bérenguer // IEEE Transactions on Reliability, Institute of Electrical and Electronics Engineers. - 2018. - Vol. 68, № 1. - P. 375396. DOI: 10.1109/TR.2018.2829771.

20. Sun Q. Scheduling preventive maintenance considering the saturation effect / Q. Sun, Z.-S. Ye, W. Peng // IEEE Transactions on reliability, Institute of Electrical and Electronics Engineers. - 2019. - Vol. 68, № 2. - P. 741752. DOI: 10.1109/TR.2018.2874265. 